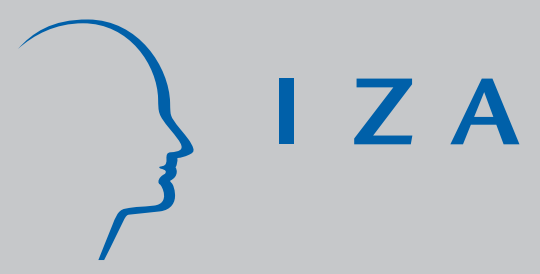

IZA DP No. 3340

Performance Spillovers and Social Network in the Workplace: Evidence from Rural and Urban Weavers in a Chinese Textile Firm

Takao Kato

Pian Shu

February 2008 


\title{
Performance Spillovers and Social Network in the Workplace: Evidence from Rural and Urban Weavers in a Chinese Textile Firm
}

\author{
Takao Kato \\ Colgate University, Columbia Business School, \\ University of Tokyo, Aarhus School of Business and IZA
}

Pian Shu

MIT

Discussion Paper No. 3340

February 2008

IZA

P.O. Box 7240

53072 Bonn

Germany

Phone: +49-228-3894-0

Fax: +49-228-3894-180

E-mail: iza@iza.org

Any opinions expressed here are those of the author(s) and not those of IZA. Research published in this series may include views on policy, but the institute itself takes no institutional policy positions.

The Institute for the Study of Labor (IZA) in Bonn is a local and virtual international research center and a place of communication between science, politics and business. IZA is an independent nonprofit organization supported by Deutsche Post World Net. The center is associated with the University of Bonn and offers a stimulating research environment through its international network, workshops and conferences, data service, project support, research visits and doctoral program. IZA engages in (i) original and internationally competitive research in all fields of labor economics, (ii) development of policy concepts, and (iii) dissemination of research results and concepts to the interested public.

IZA Discussion Papers often represent preliminary work and are circulated to encourage discussion. Citation of such a paper should account for its provisional character. A revised version may be available directly from the author. 


\section{ABSTRACT \\ Performance Spillovers and Social Network in the Workplace: Evidence from Rural and Urban Weavers in a Chinese Textile Firm ${ }^{*}$}

We provide some of the first rigorous evidence on performance spillovers and social network in the workplace. The data we use are rather extraordinary - weekly data for rejection rates (proportion of defective output) for all weavers in a firm during a 12 months (April 2003-March 2004) period, more than 10,000 observations. Our fixed effect estimates first point to significant spillovers of performance from high-ability weavers to low-ability weavers. On the other hand, we find no evidence for performance spillovers from low-ability to high-ability weavers. The findings are consistent with the knowledge sharing hypothesis that low-ability workers learn from high-ability workers but not vice versa. Second, by exploiting the welldocumented fact that an exogenously-formed sharp divide between urban workers and rural migrant workers exists in firms in Chinese cities, we find that performance spillovers/knowledge sharing take place only within the confines of social network. Specifically rural low-ability weavers are found to improve their performance as their highability teammates (who are also rural migrants) improve their performance while they do not benefit from performance improvement of their high-ability teammates who are urban residents. Such heterogeneous performance interdependence of workers within the same team suggests that our evidence for performance spillovers is less likely to be a result of team specific demand shocks that generate spurious performance interdependence of all team members.

JEL Classification: M5, J24, L2

Keywords: knowledge sharing, performance spillovers, social network

Corresponding author:

Takao Kato

Department of Economics

Colgate University

13 Oak Drive

Hamilton, NY133456

USA

E-mail: tkato@mail.colgate.edu

\footnotetext{
* The data were collected in collaboration with Xiao-Yuan Dong and Derek C. Jones to whom we are most grateful (see Dong, Jones and Kato, 2007 for details on the data). We benefitted greatly from comments from Joshua Angrist, David Autor, Michael Greenstone, Cheryl Long, Alan Manning, Matt Notowidigdo and Bruce Weinberg as well as from Lan Shi and Nachum Sicherman and other participants at the 2007 SOLE Meetings in Chicago, and seminar participants at Aarhus School of Business (Economics Seminar), Copenhagen Business School (International Economics and Management Seminar), MIT (Labor Lunch Seminar), and the University of Paris 1 (TEMA Seminar). The current version of the paper was completed while Kato was Velux Visiting Professor at ASB (Aarhus School of Business), and Kato is grateful for their hospitality.
} 


\section{Performance Spillovers and Social Network in the Workplace: Evidence from Rural and Urban Weavers in a Chinese Textile Firm}

\section{$\underline{\text { I. Introduction }}$}

Spillovers of performance among workers in the workplace occur as a result of knowledge sharing and peer pressure/monitoring. Knowledge sharing in the workplace takes a form of transfer of human capital from high-ability workers to low-ability workers as well as a form of mutual learning process for workers of equal ability to improve their performance together. Such knowledge sharing may take place on the job in the case of team production. However, even in the absence of team production, knowledge sharing may occur off the job through formal offline problem solving team activities as well as informal channels such as talking over dinner and tea in the firm's dormitory.

On the other hand, peer pressure in the workplace arises when shirking generates disutility for a worker under the presence of her coworkers. Peer pressure may also result from the worker's desire to outperform her colleagues in the workplace, and hence hard work of one worker generates hard work of her coworkers.

Economists have been increasingly aware of the importance of such spillovers of performance among workers in the workplace through knowledge sharing and peer pressure. For example, peer monitoring, knowledge sharing and hence performance spillovers among team members in the workplace play a central role in the theory of "high performance work system" or "high involvement work system” (Gant, Ichniowski and Shaw, 2002; Appelbaum, et. al., 2000). In addition, performance spillovers play an important role in economics of organization (e.g., Aoki, 1986; Kandel and Lazear, 1992), growth theory (e.g., Lucas, 1988), and FDI (e.g., Fosfuri, et. al., 2001).

However, direct evidence on such performance spillovers in the workplace is rare, for 
such evidence requires researchers to go deep inside the black-box of the firm and obtain rare access to "insider” data on performance of individual workers. Pioneering works using internal personnel data in economic research include Medoff and Abraham (1980), and Baker, Gibbs, and Holmstrom (1994a, 1994b). More recently, a number of studies (e.g. Lazear, 2000, Kleiner and Helper, 2003, Fernie and Metcalf, 1999, Paarsh and Shearer, 1999, Knez and Simester, 2001, Bandiera, Barankay and Rasul, 2005), use such “insider” data and study the effects on individual worker performance of a change in pay methods (e.g., the switch from time rates to piece rates or to performance pay). A related line of work examines the effects on individual worker performance of the shift to team-based production (e.g. Batt, 1999, Hamilton, Nickerson and Owan, 2002, and Jones and Kato, 2007). None of these studies examine performance spillovers. New econometric case studies on the subject are emerging, however. Mas and Moretti (2006) use individual productivity data on supermarket cashiers at a large supermarket chain in California and provide direct evidence on performance spillovers though peer pressure. Bandiera, Barankay and Rasul (2007) use individual productivity data on fruit pickers at a leading U.K. agriculture firm and show that workers tend to conform to their friend's productivity level. Finally, Guryan, Kroft and Notowidigdo (2007) exploit random groupings of professional golfers and test the peer effects of professional golf tournaments. Unlike the first two studies, they find no evidence for peer effects. ${ }^{1}$

In this paper we use individual performance data on weavers at a large textile firm in China and provide direct evidence on performance spillovers. Our study complements Mas and Moretti (2006), Bandiera, Barankay and Rasul (2007) and Guryan, Kroft and Notowidigdo (2007) on two important accounts.

First, our study takes advantage of the well-documented social divide between urban

\footnotetext{
${ }^{1}$ Falk and Ichino (2006) provide experimental evidence on peer effects.
} 
workers and rural migrant workers in China’s transition economy and examine for the first time potentially important interplay between performance spillovers and such exogenously-formed and clearly-defined social networks (rural migrant worker network vs. urban worker network).

The potentially important role of social network in worker's decision making has been reported in the literature (e.g., Duflo and Saez, 2004 who find that female workers' retirement investment decisions are correlated with the other female workers' decisions in the same department, but not the male workers'). Thus, it is possible that workers interact with each other mostly in sub-groups within the team. Some workers may find it easier to communicate with those who share similar characteristics such as gender or regional background. On the other hand, it is also possible that some workers prefer to learn from differences rather than similarities and thus choose to interact more with people from different backgrounds. Ultimately this is an empirical question that needs to be tested.

In the context of an urban Chinese enterprise, there is a strong social divide between urban workers and rural migrant workers. The relaxation of the regulations on rural-urban migration in 1988 encouraged many rural workers to look for a job in the urban areas and get paid higher than what they earn from doing agricultural work at home. However, it is not easy for rural migrant workers to gain an urban housing registration ("hu kou”). This tends to produce a significant entry barrier for rural migrants, and inequality between the rural and urban labor force. Without urban housing registration, rural workers are ineligible for many high-paying urban jobs as well as the urban welfare programs such as healthcare and schooling (Huang, 2001). A rural worker must also pay for a temporary residence permit in order to find a legal residence in the urban areas. In conclusion, there is significant adjustment cost for a rural migrant to work in the urban area. Huang (2001) find that a rural female migrant is usually only able to find the low-paid, 
low-benefit urban jobs. Nevertheless such jobs may still be more attractive than the limited opportunities at home.

While China has recently been reforming towards a market economy, the reform is still far from complete and the hu kou system has been standing in the way of free labor mobility (Fleisher and Yang, 2006). Furthermore, the sharp distinction between the urban and rural status may create a separate sense of identity. The rural workers are constantly reminded of being an outsider. Having been through similar difficulties working in the urban area, the rural workers in the firm may form a stronger tie among themselves. At the same time, the urban workers may find it easier to communicate with the other urban workers as they come from similar background (Nielsen, et. al., 2006 and Lu and Song, 2006).

Our ability to identify two clearly-defined and exogenously-formed social networks within the same team also provides us with an important methodological advantage. Specifically, we are able to uncover heterogeneous performance interdependence of workers within the same team (e.g., a rural migrant worker improves her performance as her rural migrant teammates improve their performance yet no such performance interdependence exists between her and her urban teammates). As such, our evidence for performance spillovers is less likely to be a result of team specific shocks that generate spurious performance interdependence of all team members.

Second, the afore-mentioned three recent working papers focus on peer pressure rather than knowledge sharing as a source of performance spillovers due to the nature of work and production technology of their subjects. The skill requirements for supermarket cashiers (in the case of Mas and Moretti, 2006) and fruit pickers (in the case of Bandiera, Barankay and Rasul, 2007) are quite low and the scope for knowledge sharing is extremely limited. Guryan, Kroft and Notowidigdo (2007) study competitive professional athletes in high-stake golf tournaments and 
knowledge sharing among these competitors during the tournament is highly unlikely. Unlike these peer effect studies, we use data from a manufacturing firm. The extensive field research at our Chinese textile firm reveals that there is significant scope for knowledge sharing among our weavers due to the nature of their work and production technology (see the next section for more details). On our reading of the literature, our paper is the first attempt to provide individual worker-level evidence on performance spillovers of workers who engage in significant knowledge sharing.

In sum, we provide some of the most reliable evidence to date on performance spillovers and social network in the workplace. The data we use are rather extraordinary -weekly data for rejection rates (proportion of defective output) for all weavers in a firm during a 12 months (April 2003-March 2004) period, including more than 10,000 observations. First, our fixed effect estimates show that performance spillovers occur from high-ability workers to low-ability workers but not from low-ability to high-ability workers. Second, social network appears to play an important role in such performance spillovers. Thus, performance of a low-ability worker is significantly influenced by performance of her high-ability teammates within the same social network (migrant workers from rural areas in the context of our Chinese textile firm) while it is not affected by performance of her high-ability teammates outside of the social network (urban workers).

This paper is organized as follows. Section II discusses the case and data. Section III reports the regression results. Section IV concludes.

\section{The Case, Data and Descriptive Statistics}

Our case, SCT, is located in an area in which many textile firms are to be found in China, 
Shijiangzhuang, the capital of Hebei province. ${ }^{2}$ Originally the firm was state-owned and suffering from the financial crisis that affected many Chinese firms during the 1990's with outdated equipment, an aging workforce, and a shrinking market contributing to the firm's difficulties. The threat of bankruptcy led to ownership restructuring as an alternative solution to closure and the value of the firm's assets was transferred completely to employees in 1998. During the study period the total labor force averaged about 3500 employees.

In collaboration with Xiao-Yuan Dong and Derek C. Jones, we collected several kinds of data from the case. ${ }^{3}$ These were collected during a lengthy study period when we visited the firm twice and met with and interviewed the Director of Human Resources, the Director of the Weaving Division, a line supervisor and two team leaders at the Weaving Division, and the Director of Data Management (who was in charge of all internal data). In addition, to get perspective from an outsider, we also interviewed a long-term consultant for SCT who has been observing the firm for many years. As well as collecting various performance and personnel data, we also deepened our knowledge of the case by collecting data from a survey that we designed and administered to all team leaders.

Our key data are a panel for all 297 weavers who worked in SCT at any time during the 12 month period spanning the first week of April 2003 to the last week of March 2004. ${ }^{4}$ We chose this group of employees because an accurate objective measure of individual worker performance with little measurement error is available consistently for all workers during this period. In addition, we were able to match these worker performance data with personnel data, using unique employee IDs. Table 1 summarizes personal characteristics of our weavers. The

\footnotetext{
${ }^{2}$ Our confidentiality agreement with SCT prohibits us from revealing the actual name of the firm.

${ }^{3}$ See Dong, Jones and Kato, 2007 for details on the data.

${ }^{4}$ There were actually a dozen of weavers in our data who worked for only one week and less than 15 hours during the week. We have no reliable performance data for such weavers.
} 
vast majority of weavers are female (97\%). The education level is uniform across the work force: all weavers have graduated from junior high school but not high school. About $63 \%$ of weavers are rural migrant workers. ${ }^{5}$

SCT uses a standard three-shift operation and each shift has six teams based on the location of the weaving rooms. Thus, there are a total number of eighteen teams. Each team has on average 10 to 11 weavers throughout the year. There was no switching of weavers between teams during the time period under study. When a new weaver joins SCT, our field research suggests that there is no systematic rule in her team assignment (for example, SCT has neither explicit nor implicit policy/practice to assign a new weaver with high-ability to a struggling team to boost its team performance). At the end of the next section, we will also show econometrically that the random team assignment hypothesis is indeed supported by the quantitative data.

A quick glance at the weaving workplace gives observers a first impression that the role of weavers in the production process is rather limited since the operation appears to be fully automated and various fabrics are produced by automated looms rather than by individual weavers. However, a closer look at the workplace reveals that weavers have significant responsibilities. For example, problems (such as broken threads) do occur from time to time and each weaver's main task is to pay close attention to her assigned loom machines (multiple loom machines are assigned to each weaver) and minimize the occurrence of such operational problems. If a problem does arise, each weaver is expected to solve the problem quickly and effectively. Good weavers will detect early signs of problems and make timely adjustments to the operational process so that problems will not fully materialize and hence no defective product will result. Should problems actually occur, the better weavers will solve them promptly and

\footnotetext{
${ }^{5}$ The data also include information on whether each weaver is an employee owner (or holding stock of SCT). We find no significant interplay between performance spillovers and employee ownership.
} 
efficiently, so that there will be minimal production of defective output. Due to the problemsolving nature of their jobs, SCT constantly tells their weavers how important quality is, and implores them to work toward "zero defects".

In short, the nature of weaving technology and the problem-solving nature of a weaver's job at SCT indicates that the most relevant and crucial performance measure for weavers is quality, which SCT measures by each weaver's weekly defect rate (percentage of defective output generated per week). We are most fortunate that SCT granted us full access to each weaver's weekly defect rate for all 297 weavers who ever worked in the Weaving Division during the 12 month study period spanning the first week of April 2003 to the last week of March 2004.

SCT requires each of the 12 teams to hold team meetings during the meal break, once or twice a month to discuss issues concerning quality and exchange each other's experience of dealing with problems arising from production. Each team is also encouraged to hold "voluntary" team meetings after work as well. According to our own survey of all team leaders, nearly all teams meet once a week (four times a month). The average team meeting lasts about an hour. In addition, each team is required to hold a training session after work at least once a week. The purpose of such sessions is to help each other enhance skill level. Each team also plans recreation activities such as picnics, sports, and so on.

In short, the main function of their team activities is knowledge sharing. In fact, it is the only "formal" mechanism for knowledge sharing among weavers. During regular work hours, weavers in the team work independently from each other. In fact, each weaver is typically assigned to more than 6 loom machines and required to pay exclusive attention to those machines. As such, during regular hours, any interactions between weavers are prohibited and do not happen. 
Our informant (HR director) however adds that there is an important informal mechanism of knowledge sharing. After work, weavers engage in knowledge sharing informally. The informal knowledge sharing mechanism is particularly important for rural migrant workers. They are mostly young single women from rural villages of Hebei Province and speak the same dialect. All of them live in the company dormitory free of charge (5 or 6 per room). As such, after work they return to the same dorm, eat dinner in the same dining hall, and often socialize together. There are ample opportunities to engage in informal knowledge sharing over dinner, tea or other social activities.

As explained above, in light of the problem solving nature of the main task of weavers, the most relevant weaver performance measure is defect rate (the percentage of defective cloth produced). The summary statistics in Table 2 show that on average, 0.25 percent of total weekly output produced by each weaver is defective. Though the magnitude of the defect rate appears small, "zero defect” is extremely difficult to achieve. In fact, during the 53-week period, no weaver was able to achieve "zero defect". This also confirms our field observation that automated loom machines are far from perfect and problems do occur from time to time. Exclusive, focused and educated attention to these machines by weavers is indeed an integral part of high-performance workplace. We also calculate the aggregate defect rate of a weaver's teammates, or the proportion of total output produced by all of her teammates that is defective.

To examine whether performance spillovers are unidirectional, we divide all weavers into high-ability and low-ability weavers (see below for precisely how we define high-ability and low-ability). If a key mechanism for performance spillovers is knowledge sharing, we are likely to observe the unidirectional performance spillovers from high-ability to low-ability but not from low-ability to high-ability. 
It is plausible that performance spillovers may be greater for those weavers who have spent more time in the team, for knowledge sharing (and peer pressure) is likely to be more relevant for such regular and incumbent team members. For example, Mas and Moretti (2006) found that cashiers whose shifts frequently overlap with each other tend to have greater amount of mutual monitoring. The scope of knowledge sharing may be greater for weavers who have worked together more and thus have developed a stronger tie. In our case, many weavers took three weeks off: one each for the Chinese New Year, the May Day vacation which the first week of May, and the National Day vacation which is the first week of October. We define the "incumbent” workers as those who have worked for 49 or more weeks, giving the workers a possible one-week absence due to personal or other reasons. There are 94 such incumbent workers, and we conduct our analysis, using data for all weavers as well as for only incumbent weavers.

Finally, our informant reports that each weaver's wage is determined by her seniority and individual performance. As shown in Dong, Jones and Kato (2007), to be consistent with the nature of main task of weavers and our informant's statement, weekly earnings of weavers are indeed found to be significantly related to their tenure and defect rates. There is clearly a monetary incentive for weavers to lower their defect rates.

Our informant also tells us that helping other weavers is not an important determinant of wage. There is no explicit and monetary incentive to help. However, participation in all team activities is mandatory and engaging in knowledge sharing is expected. We hypothesize that there is a strong norm among rural migrant workers who live in the same company dormitory, eat in the same dining hall, and socialize among themselves, and that the norm includes active knowledge sharing. 


\section{Empirical Strategy and Results}

Our baseline model, which we will build on to investigate our hypotheses concerning performance spillovers, is a simple fixed effects model:

$$
\begin{aligned}
\text { DEFRATE }_{\mathrm{it}}= & \alpha+\beta \text { TEAMDEF }_{\mathrm{it}}+\text { (individual fixed effects) } \\
& +(\text { monthly time dummies })+\gamma \mathrm{TENURE}_{\mathrm{it}}+\delta\left(\mathrm{TENURE}_{\mathrm{it}}\right)^{2}+\varepsilon_{\mathrm{it}}(1)
\end{aligned}
$$

where DEFRATE $\mathrm{it}_{\mathrm{it}}$ is defect rate of weaver $\mathrm{i}$ in week $\mathrm{t}$; TEAMDEF $F_{i t}$ is the aggregate defect rate of her teammates excluding herself. The estimated coefficients on TEAMDEF $F_{\text {it }}$ are used to test whether or not a weaver's individual performance is influenced by her teammates’ performance (our estimates may be subject to the reflection problem ${ }^{6}$ and we will address this issue as well as other concerns at the end of this section).

We include individual specific fixed effects to capture the time-invariant unobserved heterogeneity of our workers. In particular, individual specific fixed effects will attempt to control for differences among workers in their innate abilities. ${ }^{7}$ We also include 11 monthly time dummy variables to capture time-specific shocks to the firm that are common to all weavers. (There are actually 12 monthly time dummy variables from April 2003 through March 2004. We use the April 2003 time dummy variable as a reference month.)

We also consider the tenure of the worker (the number of weeks for which she has been with the firm) and its square. However, due to multicollinearity between tenure and the time dummy variables, we expect imprecise estimates for tenure. All of our results (of course except for the tenure effects) are insensitive to whether or not we include the tenure variables.

Table 3 reports the OLS estimates of Eq (1). The estimated coefficient on TEAMDEF it

\footnotetext{
${ }^{6}$ See, for instance, Manski (1993) and Haurin, Dietz and Weinberg (2002).

${ }^{7}$ Since there was no mobility of workers between teams during the time period under study, individual fixed effects also control for all time-invariant heterogeneity of teams.
} 
for the total sample of weavers is positive and statistically significant at the 1 percent level, suggesting that a one percentage-point decrease in the aggregate defect rate of the teammates will result in a 0.27 percentage-point decrease in one's own defect rate. The results are similar even when we consider only incumbent workers. ${ }^{8}$

While the results are consistent with the presence of performance spillovers among workers in the workplace, an alternative interpretation is plausible. For example, due to a certain type of demand shock, a team may be assigned to a different set of products which are inherently more complex and hence cause all team members to struggle to keep their defect rates low, resulting in performance interdependence of all team members.

However, the shock could also affect different weavers differently and provide opportunities for knowledge sharing. A high-ability worker may learn new skills and knowledge useful for adjusting effectively to new products and processes before her low-ability teammates. She will then share such new skills and knowledge with her low-ability teammates. In addition, high-ability workers could also work together to produce performance-enhancing local know ledges, resulting in horizontal performance spillovers among themselves.

To shed light on the possibility of such knowledge sharing, we define the high and low ability level according to the estimated individual weaver fixed effects. The estimates of individual fixed effects show the workers’ predicted performance holding time effects, tenure, tenure squared, and average team performance constant. A "high-ability” worker is defined as someone whose fixed effects estimate is lower than the median. Likewise, a "low-ability"

${ }^{8}$ All standard errors are corrected for heteroskedasticity but not for cluster, for in general, when cluster fixed effects are used (which is our case), usual standard errors corrected for heteroskedasticity are valid and more powerful than cluster-robust standard errors (Imbens and Wooldridge, 2007; Lecture 8). However, we did check if cluster-correction at the individual worker level makes any discernable difference in standard errors. As expected, cluster-correction caused standard errors to increase yet reassuringly almost all estimated coefficients that are statistically significant using heteroskedasticityrobust standard errors remain statistically significant even if we use cluster-robust standard errors. 
worker's fixed effects estimate is higher than the median. (Note that we are using the rate of defect cloth produced. Thus a larger number indicates a lower quality and hence low ability). Specifically, we estimate:

$$
\begin{aligned}
& \text { DEFRATE } E_{i t}=\alpha+\delta_{1} T E A M D E F_{-} H_{G I} H_{i t}+\delta_{2} T E A M D E F_{-} L O W_{i t} \\
& +(\text { individual fixed effects })+(\text { monthly time dummies })+\varepsilon_{i t}
\end{aligned}
$$

TEAMDEF_HIGH ${ }_{\mathrm{it}}$, and TEAMDEF_LOW $\mathrm{it}_{\mathrm{it}}$ are the aggregate defect rate of her highability and low-ability teammates respectively. We drop the Tenure variables for the rest of our regressions since they are insignificant and all of our results are insensitive to their inclusion. We run the above regression for four groups of weavers: the high-ability workers, the high-ability incumbent workers, the low-ability workers, and the low-ability incumbent workers. We expect unidirectional performance spillovers from high-ability workers to low-ability workers, but not the other way around. Moreover, synergic learning and local knowledge creating among highability workers are expected.

The results in Table 4 generally confirm our expectations. For the sample of low-ability weavers, as shown in Columns (iii) and (iv), the estimated coefficient on TEAMDEF_HIGH is positive and statistically significant at the 10 percent level for all low-ability weavers and at the 5 percent level for all low-ability incumbent weavers. On the other hand, the estimated coefficient on TEAMDEF_LOW is close to zero and highly insignificant. ${ }^{9}$ Low-ability weavers appear to benefit from performance improvement of their high-ability teammates while they do not benefit from their peers (low-ability teammates), suggesting the possibility of knowledge sharing from high-ability to low-ability teammates.

For the sample of high-ability weavers, as shown in Columns (i) and (ii), the estimated

${ }^{9}$ The difference between the estimated coefficient on TEAMDEF_HIGH and the estimated coefficient on TEAMDEF_LOW is also found to be statistically significant at the 5 percent level for the incumbent sample and at the 10 percent level for the total sample. 
coefficient on TEAMDEF_HIGH is positive and significant at the 1 percent level for both total and incumbent samples, suggesting a synergic learning among high-ability weavers in the same team. The estimated coefficient on TEAMDEF_LOW is much smaller and less significant (still significant at the 10 percent for the total sample but no longer significant even at the 10 percent level for the incumbent sample). ${ }^{10}$

We now turn to our key question: whether performance spillovers are molded by social network. We begin with a benchmark social network specification:

$$
\begin{aligned}
& D_{E F R A T E}=\alpha+\delta_{1} T E A M D E F_{-} R U R A L_{i t}+\delta_{2} T E A M D E F \_U R B A N_{i t} \\
& +(\text { individual fixed effects })+(\text { monthly time dummies })+\varepsilon_{i t}
\end{aligned}
$$

TEAMDEF_RURAL $L_{i t}$, and TEAMDEF_URBAN $\mathrm{i}_{\mathrm{it}}$, are the aggregate defect rate of her rural and urban teammates respectively. We estimate the above fixed effect model again for four groups of workers: the rural workers, the rural incumbent workers, the urban workers, and the urban incumbent workers.

Table 5 reports the OLS estimates of Eq. (3). The estimated coefficient on TEAMDEF_RURAL is positive and statistically significant at the 1 percent level for rural workers but not for urban workers. Likewise, the estimated coefficient on TEAMDEF_URBAN is positive and statistically significant at the 1 percent level for urban workers but not for rural workers. ${ }^{11}$ Such evidence of performance spillovers within the same social network but not across social network is found for both the total sample and the incumbent sample.

We are now ready to examine possible linkage between knowledge sharing and social

${ }^{10}$ The difference between the estimated coefficient on TEAMDEF_HIGH and the estimated coefficient on TEAMDEF_LOW is also found to be statistically significant at the 10 percent level for the incumbent sample and almost significant at the 10 percent level for the total sample.

${ }^{11}$ The difference between the estimated coefficient on TEAMDEF_RURAL and the estimated coefficient on TEAMDEF_URBAN is also found to be statistically significant at the 10 percent level for the incumbent rural workers and at the 5 percent level for the total urban workers. 
network in a full specification:

$$
\begin{aligned}
& \text { DEFRATE } E_{t}=\alpha+\delta_{1} \text { TEAMDEF }_{-} R U R A L H I G H_{i t}+\delta_{2} T_{E A M D E F} \text { RURAL LOW }_{i t} \\
& +\delta_{3} \text { TEAMDEF_URBAN HIGH }_{i t}+(\text { individual fixed effects }) \\
& +(\text { monthly time dummies })+\varepsilon_{i t}
\end{aligned}
$$

where TEAMDEF_RURALHIGH $\mathrm{it}_{\mathrm{i}}$, TEAMDEF_RURALLOW ${ }_{\mathrm{it}}$, and TEAMDEF_URBANHIGH ${ }_{\text {it }}$ are the aggregate defect rate of her rural high-ability, rural lowability, and urban high-ability teammates respectively. As show in Table 1, 21.2\% of all weavers are rural high-ability workers. Since $62.3 \%$ of all weavers are rural, about one third of rural weavers are high-ability. On the other hand, the majority of urban workers are high-ability (close to $80 \%$ ). Since there are very few urban low-ability weavers overall and such urban low-ability weavers are completely absent in some teams, we exclude them from our analysis. Thus, we estimate Eq. (4) for six different groups of weavers: (i) total rural high-ability weavers; (ii) incumbent rural high-ability weavers; (iii) total rural low-ability weavers; (iv) incumbent rural low-ability weavers; (v) total urban high-ability weavers; and (vi) incumbent urban high-ability weavers;

Table 6 reports the OLS estimates of Eq. (4) for the rural low-ability workers. The estimated coefficients on TEAMDEF_RURALHIGH are positive and statistically significant at the 1 percent level for both the total and incumbent samples whereas the estimated coefficients on TEAMDEF_RURALLOW and TEAMDEF_URBANHIGH are not statistically significant even at the 10 percent level (actually the estimated coefficients on TEAMDEF_RURALLOW are negative). ${ }^{12}$ Using the estimated coefficients on TEAMDEF_RURALHIGH, we gauge the

\footnotetext{
${ }^{12}$ The difference between the coefficient on TEAMDEF_RURALHIGH and the coefficient on TEAMDEF_RURALLOW as well as the difference between the coefficient on TEAMDEF_RURALHIGH and the coefficient on TEAMDEF_URBANHIGH are also found to be statistically significant at the 1 percent level for the incumbent sample. For the total sample, the difference between the coefficient on TEAMDEF_RURALHIGH and the coefficient on TEAMDEF_URBANHIGH
} 
magnitude of the spillover effect from high-ability rural weavers to low-ability rural weavers, A 0.1-percentage point fall in defect rate of her rural high-ability teammates from 0.21 to 0.11 will result in a 0.0176-percentage point fall (0.0326-percentage point fall for incumbent weavers) in defect rate of the average rural low-ability weaver. Since the average defect rate of rural lowability weavers is 0.255 , the estimated quality improvement amounts to a 7 -percent improvement (a 13-percent improvement for incumbent weavers). The size of the spillover effect appears to be modest yet still economically significant.

Table 7 summarizes the OLS estimates of Eq. (4) for their high-ability counterparts (rural high-ability workers). We find no statistically significant evidence for any performance spillovers for such rural high-ability workers.

The results in Table 6, combined with those in Table 7 suggest that for rural weavers in our Chinese textile firm, performance spillovers occur only from high-ability to low-ability workers within the same social network (or among rural migrant workers). In other words, neither ability differentials nor social network is sufficient for performance spillovers to occur. High-ability weavers discover a useful local knowledge to improve their performance before low-ability weavers and transmit such new knowledge to low-ability weavers but such knowledge sharing take place only within the same social network.

The above interpretation is further supported by the considerable difference in the estimated magnitude of performance spillovers between the total sample and the incumbent sample. The size of performance spillovers from rural high-ability to rural low-ability weavers almost double when we limit the sample to only incumbent workers. Opportunities for knowledge sharing must have been more limited and social ties must have been weaker for workers who have not been

is also found to be statistically significant at the 1 percent level (the difference between the coefficient on TEAMDEF_RURALHIGH and the coefficient on TEAMDEF_RURALLOW is not found to be significant at the 10 percent level). 
around much during the time period under study.

The OLS estimates of Eq. (4) for the urban high-ability workers are reported in Table 8. The estimated coefficients on TEAMDEF_URBAN HIGH are positive and statistically significant at the 1 percent level, pointing to performance spillovers amongst high-ability weavers within the urban network. The estimated coefficients on TEAMDEF_RURAL HIGH are much smaller and highly insignificant. ${ }^{13}$ Performance spillovers amongst high-ability weavers do not go beyond the urban/rural social divide, which is yet another evidence for the important role of social network in performance spillovers in the workplace. Finally, as expected, we find no statistically significant evidence for performance spillovers from low-ability to high-ability weavers.

Horizontal performance spillovers amongst high-ability weavers are found for urban workers but not for rural workers. This may be due to the fact hat the pool of high ability weavers is substantially larger in the urban network than in the rural network (close to 80 percent of urban workers are high-ability while only one thirds of rural workers are high-ability). As such, the scope for knowledge sharing may be greater among urban high-ability weavers than among rural high-ability weavers.

Finally, we address a number of concerns which may arise with our empirical strategy. First, our focus on quality (DEFRATE) poses a concern that weavers may try to reduce DEFRATE simply by reducing output. If this quality-quantity tradeoff issue were serious, our focus on quality would be misleading. However, as we discussed when describing the case, our field research suggests that the key individual performance variable for weavers at SCT is DEFRATE (quality), and while their discretionary efforts matter significantly for DEFRATE, there appears to be less room for discretion in terms of pace of production (or quantity). All

${ }^{13}$ The difference between the estimated coefficient on TEAMDEF_URBAN HIGH and the estimated coefficient on TEAMDEF_RURAL HIGH is also found to be statistically significant at the 1 percent level for the incumbent sample as well as for the total sample. 
weavers are required to fulfill planned output levels and they appear to do so on most occasions. As such, we expect the scope for the quality-quantity tradeoff to be quite limited for our weavers.

To confirm our expectation, we estimated all of the above equations augmented by output (defined as meters of cloths produced per hour by each weaver) as an additional right-hand side variable. Reassuringly we found no evidence for the quality-quantity tradeoff (or the estimated coefficients on the output measure are very small and actually negative rather than positive), and more importantly all of our results on performance spillovers change little even if we include the output measure as an additional control ${ }^{14}$

Second, as we discussed earlier, the field research suggests that assignment of new weavers to teams may be safely assumed random. Following a methodology used by Sacerdote (2001) and Guryan, Kroft, and Notowidigdo (2007), we test the random assignment assumption by using all weavers who joined SCT during the April 2003-March 2004 period and estimate:

$$
\begin{aligned}
& \text { PDEFRATE }_{i}=\alpha+\beta \text { PTEAMDEF }_{i} \\
& +(\text { Entry Week Dummy Variables })+\varepsilon_{i}
\end{aligned}
$$

where PDEFRATE is $_{\mathrm{i}}$ predicted performance of a new weaver i (measured by estimated fixed effect from the baseline model) and PTEAMDEF $F_{\mathrm{i}}$ is her teammates' predicted performance (also measured by estimated fixed effects from baseline model). The timing of each worker's entry to SCT may influence her predicted performance. To control for such time effects, we add entry week dummy variables. The estimated coefficient on PTEAMDEF $F_{i}$ turns out to be not at all significant even at the 10 percent level (t-values less than one), failing to reject the random assignment assumption (dropping the entry week dummy variables causes no discernable difference).

${ }^{14}$ These and other unreported results are available from Takao Kato at tkato@mail.colgate.edu upon request. 
Third, it may be possible that unexpected demand shocks end up affecting only a subset of teams (e.g., some teams are asked to start producing new products while the other continue to produce the same products), resulting in performance interdependence among all team members (Angrist and Lang, 2004). We have shown, however, that weavers with different ability levels and social networks respond differently to such shocks, suggesting knowledge sharing within the team. For example, performance of rural low-ability weavers is found to improve as their rural high-ability teammates improve their performance while there are no such performance spillovers from their urban teammates. It is hard to explain such asymmetric performance interdependence between urban and rural teammates who are working in the same team. Some may still argue that shocks can be specific to urban workers in the team but not to rural workers in the same team. It is highly unlikely but still conceivable that certain demand shocks cause only rural workers in the team to start producing new products while their urban teammates are producing the same products. However, we have found that even within the same rural social network, performance of low-ability weavers improves with their high-ability teammates but not with their low-ability teammates. This finding does not appear to be consistent with the aforementioned team-specific shock story.

Forth, our finding of differential performance spillovers for different types of teammates within the same team suggests that the reflection problem may be less serious in our case. For example, our key finding of significant performance spillovers from rural high-ability to rural low-ability weavers is not subject to the usual reflection feedback mechanism since we find no significant reverse performance spillovers from rural low-ability weavers to rural high-ability weavers. 


\section{$\underline{\text { IV. Concluding Remarks }}$}

We have provided some of the first rigorous evidence on performance spillovers and social network in the workplace. The data we use are rather extraordinary -weekly data for rejection rates (proportion of defective output) for all weavers in a firm during a 12 months (April 2003-March 2004) period, more than 10,000 observations. Our fixed effect estimates first point to significant spillovers of performance from high-ability weavers to low-ability weavers. On the other hand, we have found no evidence for performance spillovers from low-ability to high-ability weavers. The findings are consistent with the knowledge sharing hypothesis that high-ability workers acquire valuable local knowledge and then share it with low-ability workers.

Second, we have further investigated possible interplay between such performance spillovers and social network. By exploiting the well-documented fact that an exogenouslyformed sharp divide between urban workers and rural migrant workers exists in firms in Chinese cities, we have found evidence that performance spillovers take place only within the confines of social network. Specifically rural low-ability weavers are found to improve their performance as their high-ability teammates (who are also rural migrants) improve their performance while rural low-ability weavers do not benefit from performance improvement of their high-ability teammates who are not rural migrants.

Such heterogeneous performance interdependence of workers within the same team suggests that our evidence for performance spillovers is less likely to be a result of team-specific shocks that generate spurious performance interdependence of all team members.

Finally, unfortunately we are unable to perform rigorous and decisive test on whether performance spillovers we observe are due to knowledge sharing or peer pressure. However, based on our field research which points to the firm's strong emphasis on knowledge sharing 
among their workers and the presence of rich opportunities (both formal and informal) for workers to engage in knowledge sharing, we are inclined to argue that the bulk of performance spillovers we observe are likely to be due to knowledge sharing. Furthermore, Mas and Moretti (2006) show that the peer effect is observed only when workers are watched by other workers. Each of our weavers is assigned to six or more loom machines and is required to pay exclusive, focused and educated attention to those assigned machines. She rarely has an opportunity to observe how well her teammates are working. In addition, Bandiera, Barankay and Rasul (2007) find that performance spillovers due to peer pressure tend to work not only from high-ability workers to low-ability workers (low-ability workers improve their performance to match their high-ability workers who are their friends) but also from low-ability to high-ability workers (high-ability workers lower their performance to match their low-ability workers who are their friends). The performance spillovers we observe are, however, unidirectional (only from highability to low-ability workers not vice versa). In sum, knowledge sharing through formal mechanism (team meetings and training sessions) and informal mechanism (living in the same dormitory and socializing among themselves) appears to be a more plausible interpretation of our observed performance spillovers. 


\section{References}

Angrist, Joshua D. and Lang, Kevin. "Does School Integration Generate Peer Effects? Evidence from Boston's Metco Program." American Economic Review, 2004, 94(5), pp. 1613-34.

Aoki, Masahiko. "Horizontal Vs. Vertical Information Structure of the Firm." American Economic Review, 1986, 76(5), pp. 971-83.

Appelbaum, Eileen; Thomas Bailey; Peter Berg and Kalleberg, Arne L. Manufacturing Advantage: Why High-Performance Work Systems Pay Off. Ithaca and London: Cornell University Press, ILR Press, 2000.

Baker, George; Gibbs, Michael and Holmstrom, Bengt. "The Internal Economics of the Firm: Evidence from Personnel Data." Quarterly Journal of Economics, 1994a, 109(4), pp. 881-919.

. "The Wage Policy of a Firm." Quarterly Journal of Economics, 1994b, 109(4), pp. 921-55.

Bandiera, Oriana; Barankay, Iwan and Rasul, Imran. "Social Incentives in the Workplace," Paper presented at the NBER Summer Institute, 2007.

. "Social Preferences and the Response to Incentives: Evidence from Personnel Data." Quarterly Journal of Economics, 2005, 120(3), pp. 917-62.

Batt, Rosemary. "Work Organization, Technology, and Performance in Customer Service and Sales." Industrial and Labor Relations Review, 1999, 52(4), pp. 539-64.

Dong, Xiao-yuan; Jones, Derek C. and Kato, Takao. "Experience, Productivity, Teams and Wages: An Empirical Analysis Using Panel Data on Individual Worker Output," IZA Discussion Paper No. 3122, 2007.

Duflo, Esther and Saez, Emmanuel. "The Role of Information and Social Interactions in Retirement Plan Decisions: Evidence from a Randomized Experiment." Quarterly Journal of Economics, 2003, 118(3), pp. 815-42.

Falk, Armin and Ichino, Andrea. "Clean Evidence on Peer Effects." Journal of Labor Economics, 2006, 24(1), pp. 39-57.

Fernie, Sue and Metcalf, David. "It's Not What You Pay It's the Way That You Pay It and That's What Gets Results: Jockeys' Pay and Performance." Labour, 1999, 13(2), pp. 385-411.

Fleisher, Belton M. and Yang, Dennis Tao. "Problems of China's Rural Labor Markets and Rural-Urban Migration." Chinese Economy, 2006, 39(3), pp. 6-25.

Fosfuri, Andrea; Motta, Massimo and Ronde, Thomas. "Foreign Direct Investment and Spillovers through Workers' Mobility." Journal of International Economics, 2001, 53(1), pp. 205-22.

Gant, Jon; Ichniowski, Casey and Shaw, Kathryn. "Social Capital and Organizational Change in High-Involvement and Traditional Work Organizations." Journal of Economics and Management Strategy, 2002, 11(2), pp. 289-328.

Guryan, Jonathan; Kroft, Kory and Notowidigdo, Matt. "Peer Effects in the Workplace: Evidence from Random Groupings in Professional Golf Tournaments," National Bureau of Economic Research, Inc, NBER Working Papers: 13422, 2007.

Hamilton, Barton H.; Nickerson, Jack A. and Owan, Hideo. "Team Incentives and Worker Heterogeneity: An Empirical Analysis of the Impact of Teams on Productivity and Participation." Journal of Political Economy, 2003, 111(3), pp. 465-98.

Hansen, Daniel G. "Worker Performance and Group Incentives: A Case Study." Industrial and Labor Relations Review, 1997, 51(1), pp. 37-49. 
Haurin, Donald R.; Dietz, Robert D. and Weinberg, Bruce A. "The Impact of Neighborhood Homeownership Rates: A Review of the Theoretical and Empirical Literature." Journal of Housing Research, 2002, 13(2), pp. 119-51.

Huang, Youqin. "Gender, Hukou, and the Occupational Attainment of Female Migrants in China (1985-1990)." Environment and Planning A, 2001, 33(2), pp. 257-79.

Imbens, Guido and Wooldridge, Jeffrey. "What's New in Econometrics?" NBER Summer Institute. Cambridge, Massachusetts, 2007.

Jones, Derek C. and Kato, Takao. "The Impact of Teams on Output, Quality and Downtime: An Empirical Analysis Using Individual Panel Data," IZA Discussion Paper No. 2917, 2007.

Kandel, Eugene and Lazear, Edward P. "Peer Pressure and Partnerships." Journal of Political Economy, 1992, 100(4), pp. 801-17.

Kleiner, Morris and Helper, Susan. "Changing Incentives for Production Employees: Impacts on Establishment Economic Outcomes and Worker Satisfaction," Paper presented at the 55th IRRA meeting, Washington, D.C., 2003.

Knez, Marc and Simester, Duncan. "Firm-Wide Incentives and Mutual Monitoring at Continental Airlines." Journal of Labor Economics, 2001, 19(4), pp. 743-72.

Lazear, Edward P. "Performance Pay and Productivity." American Economic Review, 2000, 90(5), pp. 1346-61.

Lu, Zhigang and Song, Shunfeng. "Rural-Urban Migration and Wage Determination: The Case of Tianjin, China." China Economic Review, 2006, 17(3), pp. 337-45.

Lucas, Robert E., Jr. "On the Mechanics of Economic Development." Journal of Monetary Economics, 1988, 22(1), pp. 3-42.

Manski, Charles F. "Identification of Endogenous Social Effects: The Reflection Problem." Review of Economic Studies, 1993, 60(3), pp. 531-42.

Mas, Alexandre and Moretti, Enrico. "Peers at Work," National Bureau of Economic Research, Inc, NBER Working Papers: 12508, 2006.

Medoff, James L. and Abraham, Katharine G. "Experience, Performance, and Earnings." Quarterly Journal of Economics, 1980, 95(4), pp. 703-36.

. "Experience, Performance, and Earnings." Quarterly Journal of Economics, 1980, 95(4), pp. 703-36.

Nielsen, Ingrid; Nyland, Chris; Smyth, Russell; Zhang, Mingqiong and Zhu, Cherrie Jiuhua. "Effects of Intergroup Contact on Attitudes of Chinese Urban Residents to Migrant Workers." Urban Studies, 2006, 43(3), pp. 475-90.

Paarsch, Harry J. and Shearer, Bruce S. "The Response of Worker Effort to Piece Rates: Evidence from the British Columbia Tree-Planting Industry." Journal of Human Resources, 1999, 34(4), pp. 643-67.

Sacerdote, Bruce. "Peer Effects with Random Assignment: Results for Dartmouth Roommates." Quarterly Journal of Economics, 2001, 116(2), pp. 681-704. 
Table 1 - Descriptive Statistics: Weavers' Individual Characteristics

\begin{tabular}{||llrrr||}
\hline Variable & Definition & Mean & S.D. & N \\
\hline GENDER & $=1$ if the weaver is female & 0.966 & 0.181 & 297 \\
EDUC & $=1$ if the highest education is middle school & 1.000 & 0.000 & 297 \\
RURAL & $=1$ if the weaver has rural registration & 0.667 & 0.472 & 297 \\
TEAMSIZE & Average number of weavers in the team & 10.579 & 1.343 & 18 \\
RURAL*HIGH & $=1$ if the weaver is rural and high-ability & 0.212 & 0.410 & 297 \\
\hline
\end{tabular}

Source: All data provided by SCT. Data are for 297 weavers at SCT during the 53-week period from the first week of April, 2003 to the last week of March, 2004. 
Table 2 - Summary of Statistics: Variables in the Analysis

\begin{tabular}{|c|c|c|c|}
\hline Variable & Definition & Mean & S.D. \\
\hline DEFRATE & $=100 *$ Defect cloth $/$ Total output & 0.247 & 0.347 \\
\hline TENURE & $=$ Number of weeks been at the firm & 466.517 & 301.158 \\
\hline TENURE $^{2}$ & $=$ TENURE*TENURE & 308325.600 & 331677.200 \\
\hline TEAM DEF & Aggregate defect rate of the teammates & 0.229 & 0.078 \\
\hline RURAL HIGH DEF & $\begin{array}{l}\text { Aggregate defect rate of the rural high- } \\
\text { ability workers in the team }\end{array}$ & 0.210 & 0.114 \\
\hline URBAN HIGH DEF & $\begin{array}{l}\text { Aggregate defect rate of the urban high- } \\
\text { ability workers in the team }\end{array}$ & 0.223 & 0.120 \\
\hline RURAL LOW DEF & $\begin{array}{l}\text { Aggregate defect rate of the rural low- } \\
\text { ability workers in the team }\end{array}$ & 0.255 & 0.136 \\
\hline URBAN LOW DEF & $\begin{array}{l}\text { Aggregate defect rate of the urban low- } \\
\text { ability workers in the team }\end{array}$ & 0.257 & 0.281 \\
\hline
\end{tabular}

Source: All data provided by SCT. Data are for 297 weavers at SCT during the 53-week period from the first week of April, 2003 to the last week of March, 2004. 
Table 3 - The Fixed Effect Estimates of Performance Spillovers:

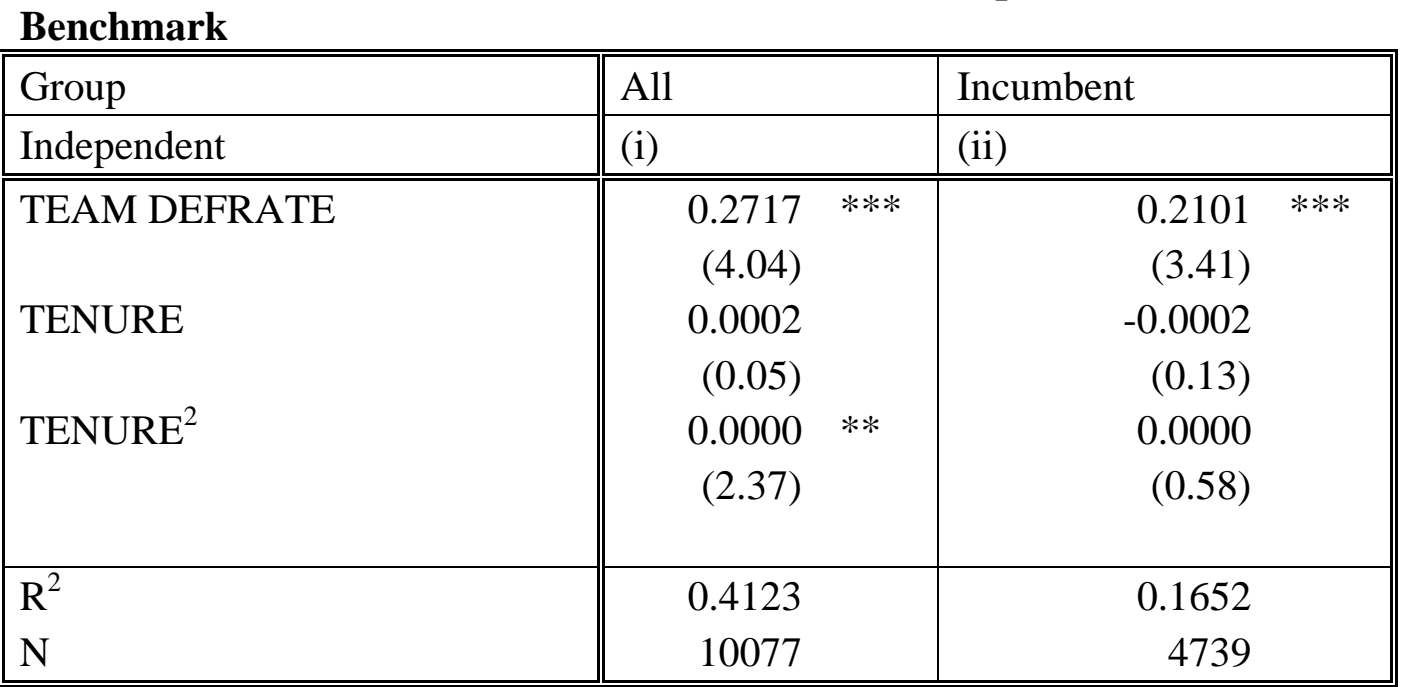

Source: All data provided by SCT. Data are for 297 weavers at SCT during the 53-week period from the first week of April, 2003 to the last week of March, 2004.

The 1-week temporary workers are excluded, all of who worked for less than 15 hours during the week.

All models include individual fixed effects and monthly time dummy variables. Standard errors are corrected for heteroskedasticity.

***statistically significant at the $1 \%$ level **statistically significant at the $5 \%$ level *statistically significant at the $10 \%$ level 
Table 4 - The Fixed Effects Estimate of Performance Spillovers: High-ability vs. Low-ability Workers

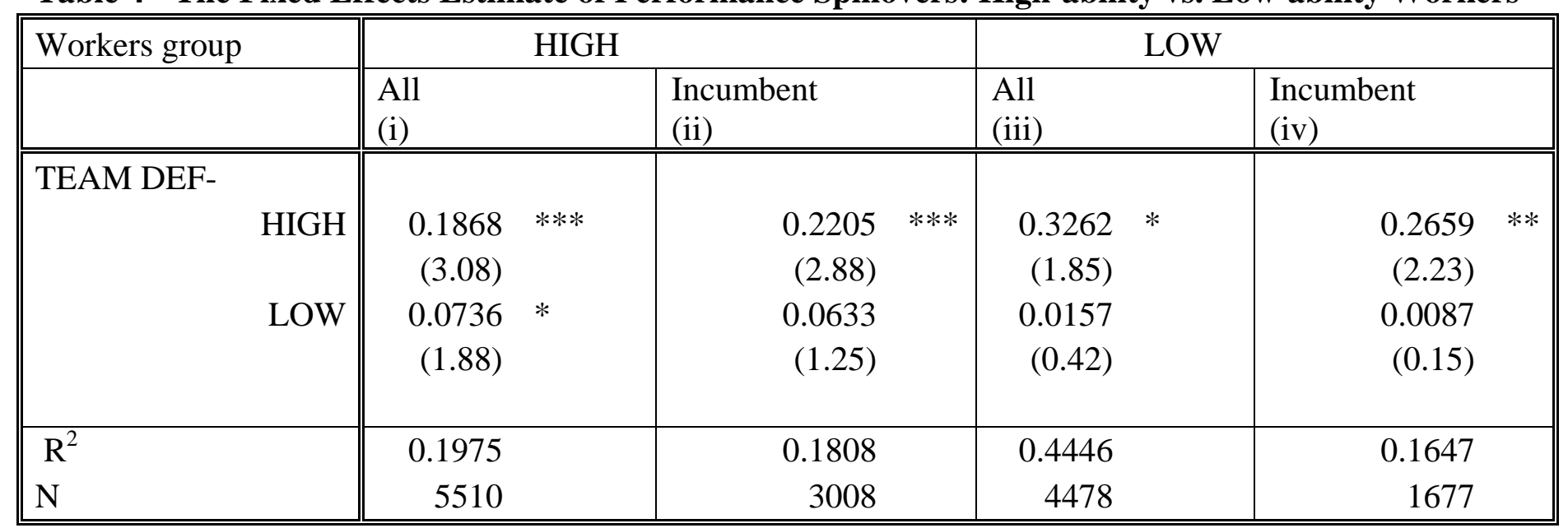

Source: All data provided by SCT. Data are for 297 weavers at SCT during the 53-week period from the first week of April, 2003 to the last week of March, 2004.

The 1-week temporary workers are excluded, all of who worked for less than 15 hours during the week.

All models include individual fixed effects and monthly time dummy variables. Standard errors are corrected for heteroskedasticity.

The results are insensitive to whether or not tenure and tenure*tenure are included. Absolute values of $\mathrm{t}$ statistics are in parentheses.

***statistically significant at the $1 \%$ level **statistically significant at the $5 \%$ level *statistically significant at the $10 \%$ level 
Table 5 - The Fixed Effects Estimate of Performance Spillovers: Rural vs. Urban Workers

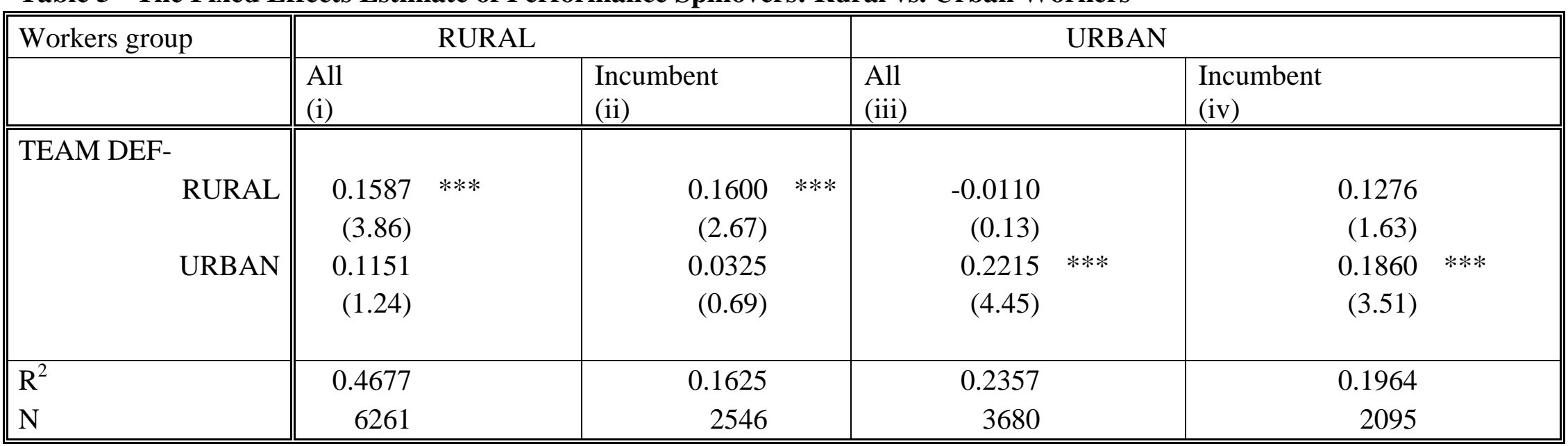

Source: All data provided by SCT. Data are for 297 weavers at SCT during the 53-week period

from the first week of April, 2003 to the last week of March, 2004.

The 1-week temporary workers are excluded, all of who worked for less than 15 hours during the week.

All models include individual fixed effects and monthly time dummy variables. Standard errors are corrected for heteroskedasticity.

The results are insensitive to whether or not tenure and tenure*tenure are included. Absolute values of $t$ statistics are in parentheses.

${ }^{* * *}$ statistically significant at the $1 \%$ level. ${ }^{* *}$ statistically significant at the $5 \%$ level. *statistically significant at the $10 \%$ level. 
Table 6 - The Fixed Effects Estimate of Performance Spillovers on Rural LowAbility Workers

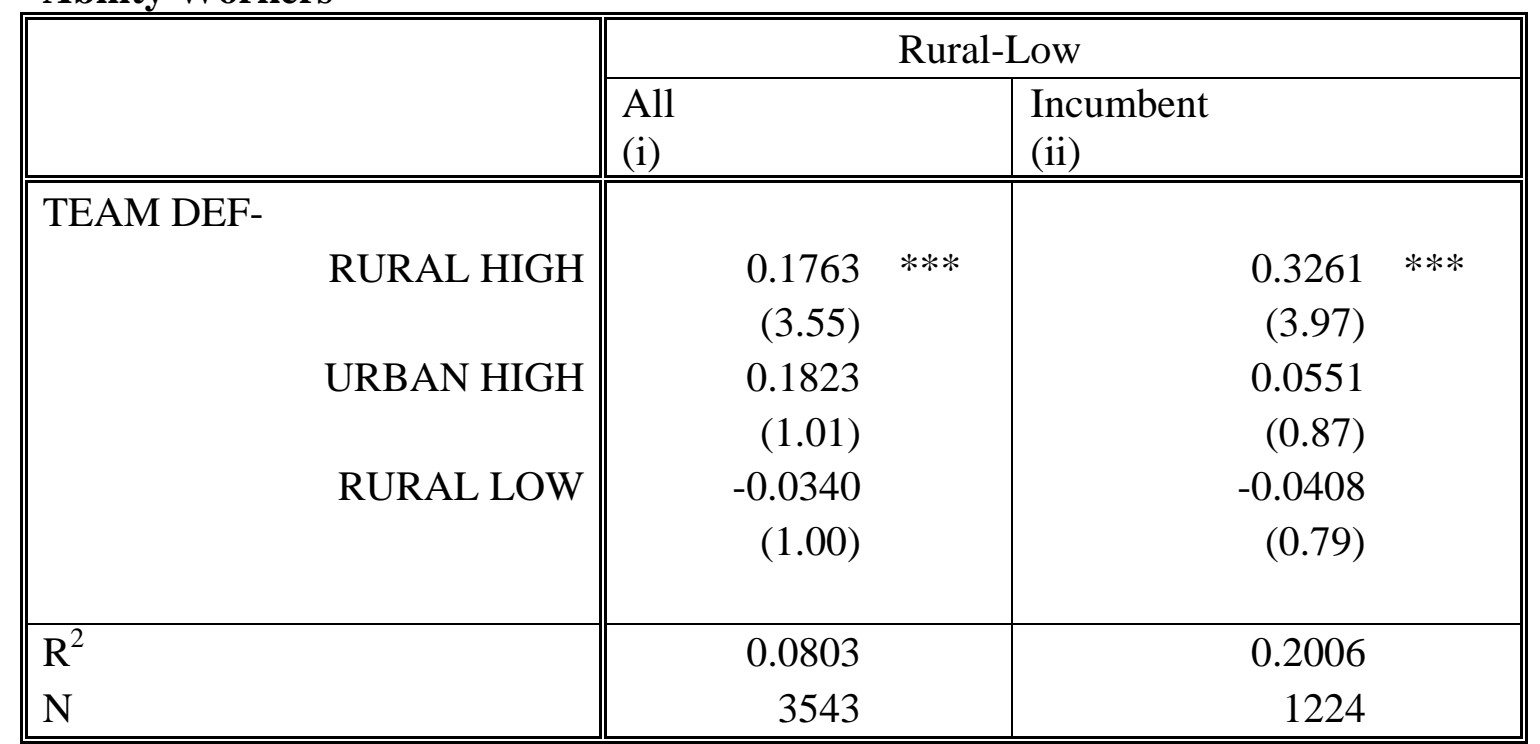

Source: All data provided by SCT. Data are for 297 weavers at SCT during the 53-week period from the first week of April, 2003 to the last week of March, 2004.

The 1-week temporary workers are excluded, all of who worked for less than 15 hours during the week. All models include individual fixed effects and monthly time dummy variables. Standard errors are corrected for heteroskedasticity.

***statistically significant at the $1 \%$ level. ${ }^{* *}$ statistically significant at the $5 \%$ level. *statistically significant at the $10 \%$ level. 
Table 7 - The Fixed Effects Estimate of Performance Spillovers on Rural HighAbility Workers

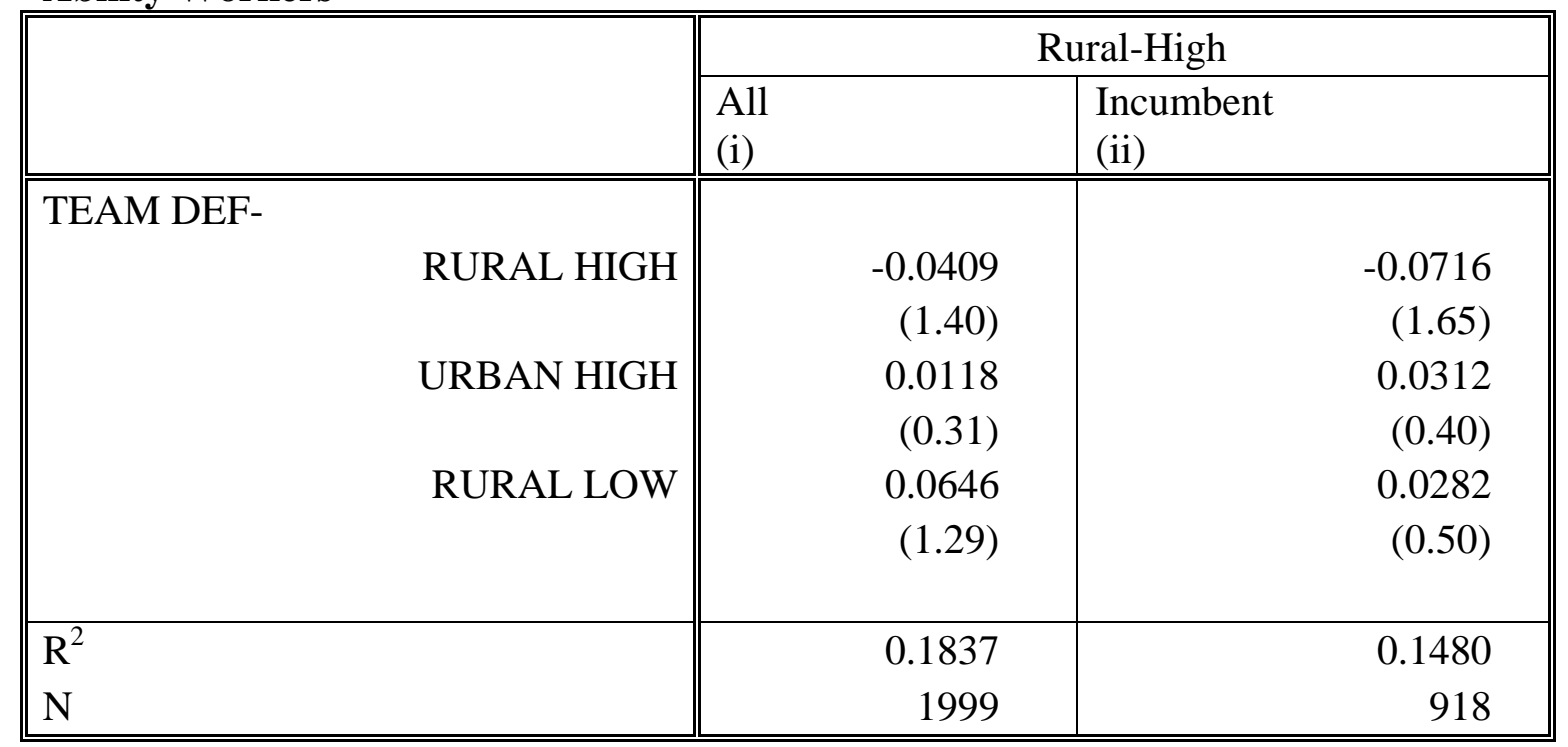

Source: All data provided by SCT. Data are for 297 weavers at SCT during the 53-week period from the first week of April, 2003 to the last week of March, 2004.

The 1-week temporary workers are excluded, all of who worked for less than 15 hours during the week. All models include individual fixed effects and monthly time dummy variables. Standard errors are corrected for heteroskedasticity.

***statistically significant at the $1 \%$ level. ${ }^{* *}$ statistically significant at the $5 \%$ level. *statistically significant at the $10 \%$ level. 
Table 8 - The Fixed Effects Estimate of Performance Spillovers on Urban HighAbility Workers

\begin{tabular}{|c|c|c|c|c|c|}
\hline & \multicolumn{4}{|c|}{ Urban-High } \\
\hline & & \multicolumn{2}{|l|}{$\begin{array}{l}\text { All } \\
\text { (i) }\end{array}$} & \multicolumn{2}{|l|}{\begin{tabular}{|l|} 
Incumbent \\
(ii)
\end{tabular}} \\
\hline \multicolumn{6}{|c|}{ TEAM DEF- } \\
\hline & URBAN HIGH & 0.2239 & $* * *$ & 0.2387 & $* * *$ \\
\hline & & (4.99) & & $(4.88)$ & \\
\hline & RURAL HIGH & 0.0150 & & 0.0342 & \\
\hline & & $(0.47)$ & & $(0.95)$ & \\
\hline & RURALLOW & -0.0346 & & -0.0392 & \\
\hline & & $(0.193)$ & & $(0.87)$ & \\
\hline $\mathrm{R}^{2}$ & & 0.2400 & & 0.2440 & \\
\hline $\mathrm{N}$ & & 2631 & & 1410 & \\
\hline
\end{tabular}

Source: All data provided by SCT. Data are for 297 weavers at SCT during the 53-week period from the first week of April, 2003 to the last week of March, 2004.

The 1-week temporary workers are excluded, all of who worked for less than 15 hours during the week. All models include individual fixed effects and monthly time dummy variables. Standard errors are corrected for heteroskedasticity.

*** statistically significant at the $1 \%$ level. ${ }^{* *}$ statistically significant at the $5 \%$ level. *statistically significant at the $10 \%$ level. 